\title{
LIFE CYCLE ASSESSMENT OF PROCESSING FOR CHROME TANNED COWHIDE UPPER LEATHER
}

\author{
Heng YANG ${ }^{1}$, Dexin $\mathrm{AN}^{1}$, Carmen GAIDAU ${ }^{2}$, Jinwei ZHANG ${ }^{1}$, Jin ZHOU ${ }^{1 *}$ \\ ${ }^{1}$ National Engineering Laboratory for Clean Technology of Leather Manufacture, Sichuan University, Chengdu 610065, P.R. \\ China; 1518449567@qq.com, 1946828368@qq.com, scutanner@163.com,zj_scu@scu.edu.cn
}

${ }^{2}$ Leather Research Department, INCDTP - Division: Leather and Footwear Research Institute, Bucharest 031215, Romania; carmen_gaidau@hotmail.com

\section{LIFE CYCLE ASSESSMENT OF PROCESSING FOR CHROME TANNED COWHIDE UPPER LEATHER}

ABSTRACT. Pollution has become a serious problem in leather industry, however, current method to evaluate its environmental effect usually used data from literature review, those data generated while leather manufacturing were rarely collected and analyzed. Thereby, the aim of this study was to evaluate the environmental effect of manufacturing process of chrome tanned cowhide upper leather by applying the Life Cycle Assessment protocols. Following the guidance of ISO 14010, we first combined data obtained from field study and empirical review; and then these data were input into eFootprint for calculation. Results, including four environmental indicators (global warming potential [GWP], primary energy demand [PED], water utility [WU] and acidification [AP]), show that producing $1 \mathrm{~kg}$ of cowhide upper leather releases $7.040 \mathrm{~kg}$ of $\mathrm{CO}_{2}$ eq, consumes $106.793 \mathrm{MJ}$ of energy and $89.144 \mathrm{~kg}$ of water and emits $0.058 \mathrm{~kg} \mathrm{of} \mathrm{SO} \mathrm{C}_{2}$ eq. Sensitivity analysis of inventory data demonstrated that chrome tanning and retanning processes accounted for more than $40 \%$ of PED, AP and GWP, whereas the beamhouse was more than $78 \%$ of WU. Therefore, we could optimise the tanning process by using alternative materials or technologies in the critical sections to achieve cleaner production and sustainable leather manufacturing.

KEYWORDS: life cycle assessment, leather processing, leather cleaner production, carbon footprint

EVALUAREA CICLULUI DE VIAṬĂ PENTRU PRELUCRAREA PIELII BOVINE TĂBĂCITE ÎN CROM PENTRU FEṬE ÎNCĂLȚĂMINTE

REZUMAT. Poluarea a devenit o problemă serioasă în industria de pielărie; cu toate acestea, metoda actuală de evaluare a efectului său asupra mediului a folosit deseori datele din literatură, rareori colectându-se și analizându-se date generate în procesul de fabricare a pielii. Prin urmare, scopul acestui studiu a fost de a evalua efectul asupra mediului al procesului de fabricare a pielii bovine tăbăcite în crom pentru fețe încălțăminte prin aplicarea protocoalelor de evaluare a ciclului de viață. Urmărind indicațiile prevăzute în ISO 14010, s-au combinat mai întâi datele obținute din studiul de teren și datele empirice, apoi aceste date au fost introduse în programul efootprint pentru calcul. Rezultatele, inclusiv patru indicatori de mediu (potențialul de încălzire globală [GWP], cererea de energie primară [PED], utilitatea apei [WU] și acidificarea [AP]), arată că în urma fabricării a $1 \mathrm{~kg}$ de piele bovină pentru fețe încălțăminte se eliberează 7,040 kg de $\mathrm{CO}_{2}$ echivalent, se consumă 106,793 MJ de energie și 89,144 kg de apă și se emit 0,058 kg de SO 2 echivalent. Analiza de senzitivitate a datelor de inventar a demonstrat că procesele de tăbăcire și retăbăcire în crom au reprezentat mai mult de $40 \%$ din PED, AP și GWP, în timp ce procesele de înmuiere și cenușărire a depășit $78 \%$ din WU. Prin urmare, procesul de tăbăcire ar putea fi optimizat utilizând materiale sau tehnologii alternative în secțiunile critice pentru a realiza o producție mai curată și sustenabilă a pielii.

CUVINTE CHEIE: evaluarea ciclului de viață, prelucrarea pielii, fabricarea pielii prin procese ecologice, amprentă de carbon

ÉVALUATION DU CYCLE DE VIE POUR LE TRAITEMENT DU CUIR BOVIN TANNÉ AU CHROME POUR TIGES CHAUSSURES

RÉSUMÉ. La pollution est devenue un problème sérieux dans l'industrie du cuir ; cependant, la méthode actuelle d'évaluation de son effet sur l'environnement a souvent utilisé des données de la littérature, tandis que les données générées dans le processus de fabrication du cuir ont rarement été recueillies et analysées. Par conséquent, le but de cette étude était d'évaluer l'effet environnemental du processus de fabrication du cuir bovine tanné au chrome pour les tiges chaussures en appliquant des protocoles d'évaluation du cycle de vie. Suivant les indications fournies dans l'ISO 14010, les données issues de l'étude de terrain et les données empiriques ont d'abord été combinées, puis ces données ont été saisies dans le logiciel eFootprint pour le calcul. Les résultats, dont quatre indicateurs environnementaux (potentiel de réchauffement planétaire [GWP], demande d'énergie primaire [PED], service d'eau [WU] et acidification [AP]), montrent qu'après la fabrication de $1 \mathrm{~kg}$ de cuir bovin pour chaussures $7040 \mathrm{~kg}$ de CO 2 équivalent sont libérés, $106793 \mathrm{MJ}$ d'énergie et $89144 \mathrm{~kg}$ d'eau sont consommés et $0,058 \mathrm{~kg}$ d'équivalent $\mathrm{SO}_{2}$ est émis. L'analyse de sensibilité des données d'inventaire a montré que les processus de tannage et de retannage au chrome représentaient plus de $40 \%$ des PED, AP et GWP, tandis que le travail de rivière dépassait $78 \%$ de WU. Par conséquent, le processus de tannage pourrait être optimisé en utilisant des matériaux ou technologies alternatives dans les sections critiques pour obtenir une production de cuir plus propre et durable.

MOTS CLÉS : analyse du cycle de vie, traitement du cuir, production de cuir plus propre, empreinte carbone

\section{INTRODUCTION}

China has become the largest leather producer in the world [1]. However, pollution resulting from the leather-making process continuously affects the environment, making the future of the tannery industry pessimistic. Light leather (mainly chrome tanned leather)

\footnotetext{
* Correspondence to: Assoc. Prof. Dr. Jin ZHOU, National Engineering Laboratory for Clean Technology of Leather Manufacture, Sichuan University; Chengdu 610065, P. R. China (Fax:008613880467494.zj_scu@scu.edu.cn)
} 
production in China has shown a downward trend since 2012. Furthermore, monitored by the China Leather Industry Association [2], the production of standard light leather and the income of leather industry decreased by $10.93 \%$ and $2.23 \%$, respectively, in 2019 . In addition to being affected by the economic environment, pollution is a significant factor affecting the development of the leather industry. Therefore, pollution in the leather industry should be seriously considered to achieve sustainable development.

At present, the major pollutants in the leather industry include tannery effluent, solid waste, sludge and waste gas. The components of these pollutants mainly include protein, chromium, sodium chloride, sulfate, sulfide and so on. Current data reveal that the amount of water discharged by the Chinese leather industry is approximately 120 million tonnes a year [3]. Meanwhile, $500-600 \mathrm{~kg}$ of solid waste and 35-40 tonnes of effluent containing different chemicals are generated to convert 1 tonne of raw hide into finished leather $[4,5]$. Therefore, studies focusing on the leather manufacturing process should be taken into consideration before developing pollution reduction strategies and the manufacturing process of leather products must be evaluated and analysed to identify the source and degree of pollution. In this manner, the production process can be optimised, consequently reducing waste emissions and achieving the goal of sustainable development.

Life cycle assessment (LCA) is a widely accepted methodology that has proven its efficiency as a decision-making tool for the assessment of environmental burdens associated with production processes; this approach is used to move towards sustainable production practices [6]. The relevant algorithms also include: Input-Output Analysis (IOA) and Hybrid Life Cycle Assessment (HLCA). Among them, LCA is specialised on the assessment of environmental links within manufacturing processes in terms of energy consumption, material utilisation and environmental waste emissions [7]; the method can accurately identify the processes with a great impact on surroundings and thus can provide suggestions for the reduction of environmental pollution. Therefore, LCA is an effective method that can provide reference and strategy for clean and sustainable processes in tannery.

Currently, LCA has been applied in the leather industry. Aiming for usage in sports shoes, Chen et al. [8] evaluated the carbon footprint of finished leather which specially used for sport shoes. Their results suggested that the average power consumption was the largest factor causing carbon emissions, followed by the consumption of acrylic resin, and chromium tanning agent; meanwhile, the amount of carbon dioxide emission was related to thickness of finished leather. Chen et al. [9] compared the differences of carbon dioxide emissions of cowhide upper leather among distinctive countries and found that average power consumption is the largest factor causing carbon emissions, followed by the consumption of acrylic resin and chromium tanning agent. LCA was also conducted on a new continuous system consisting of dehydration and tanning and post-tanning by immersion versus [10]; the results showed that a reduction in the use of acetone during the process positively affects the environmental outcomes. However, the above studies either lack practical data or have an incomplete assessment process; hence, a comprehensive analysis of LCA for cowhide upper leather manufacturing processes is still needed.

Therefore, this study aims to use LCA in assessing the impact of the intact leathermaking process of chrome tanned cowhide upper leather on the environment by using practical data. Moreover, it aims to explore the major contributing factors during production. Suggestions are provided by virtue of inventory data sensitivity.

\section{METHODS}

On the basis of the ISO 14040 environmental management system [11], LCA of $1 \mathrm{~kg}$ of chrome tanned cowhide upper leather was divided into four sections: target and scope determination, life cycle inventory analysis ( $\mathrm{LCl})$, life cycle impact assessment (LCIA) and result interpretation. The reason why chrome tanned cowhide upper leather was chosen as the research object was because of its large output and representative 
production process. eFootprint software (online version, IKE Environmental Technology Co., Ltd., China) was utilised for the modelling process. This protocol was developed by IKE and was designed for LCA studies [12], where functions, such as supply chain data survey, database processing, LCA modelling and analysis and data distribution are embedded.

\section{Target and Scope Determination}

In accordance with the modelling principle of 'cradle to door', the target was first determined to quantify environmental impact from raw materials to finished leather using chrome tanning technology. Chrome tanning technology means that chrome powder was used as tanning agent. Then, the key contributing factors were identified by assessing the contribution rate of each process.

The overall scope was determined as material and energy input-output and pollutant emissions when $1 \mathrm{~kg}$ cowhide upper leather was produced. Furthermore, the technology included beamhouse, tanning and finishing section, excluding the construction stage of the machine and workshop. The beamhouse mainly included processing raw hide into pelt suitable for tanning, removing hair, grease, dirt and unnecessary skin tissue, and loosening collagen fibers moderately. Tanning section referred to the conversion of pelt into leather. Finishing section's purpose was to make leather meet the requirements in appearance and service performance. The boundary of the LCA system is shown in Figure 1.

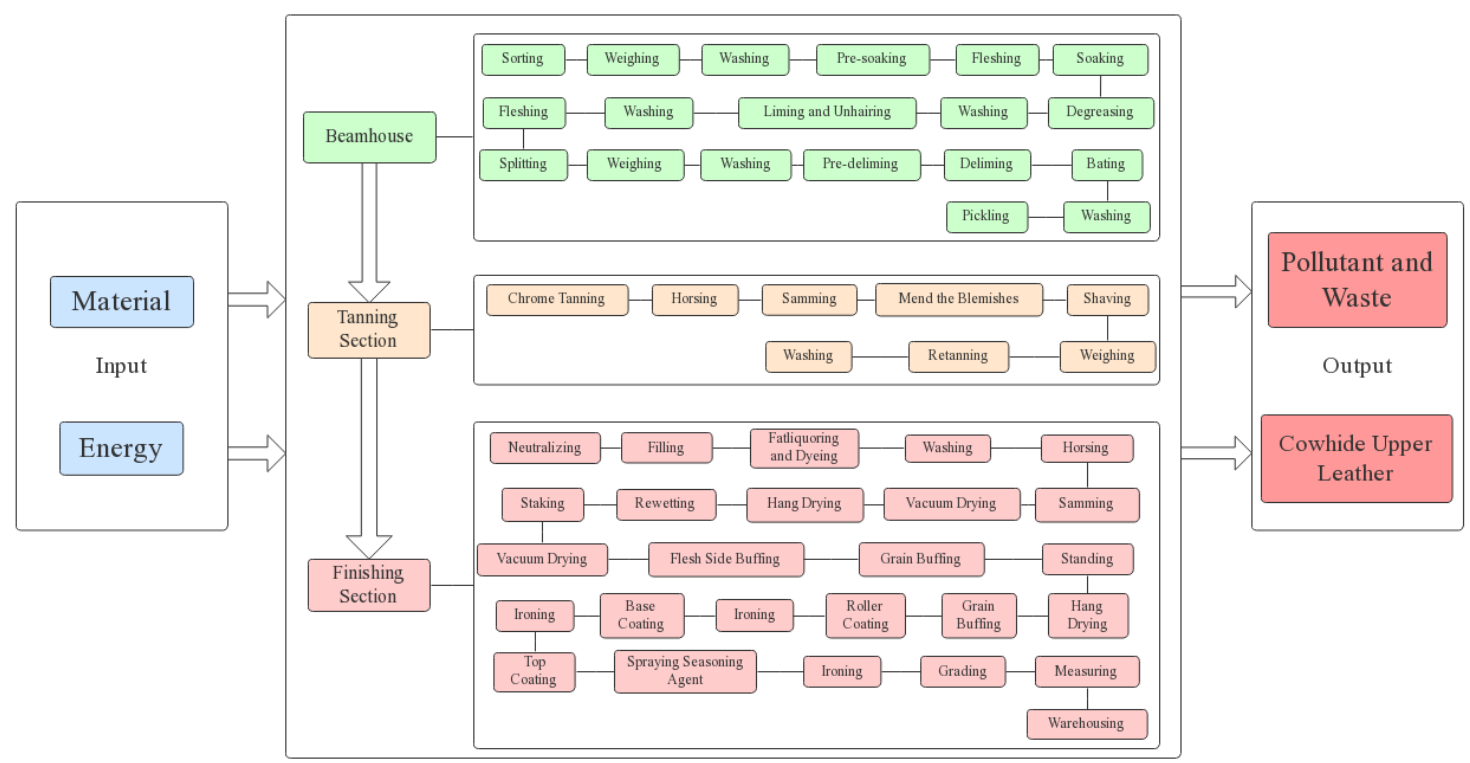

Figure 1. System boundary of chrome tanned cowhide upper leather

\section{Life Cycle Inventory Analysis}

Life cycle inventory analysis (LCl) refers to the quantitative analysis of the input for all substances, energy and discharge of pollutant waste within the system's boundary, covering all the processes and activities of manufacturing. To quantify $\mathrm{LCl}$, we executed inventory data sensitivity, which expresses the contribution rate of each production process in each indicator. In accordance with $\mathrm{LCl}$, optimisation and improvement throughout the process could be achieved.
Data was collected from our laboratory's workshop; the detailed list is shown in Table 1. Dosage of raw materials was adjusted according to the change of leather weight during the production process. Majority of upstream data were from the CLCD-ChinaECER 0.8.1 and Ecoinvent databases, which were included in eFootprint; however, a few empirical data were cited in accordance with relevant literature. For instance, leather yield was reported as $20 \%-25 \%$ [13]; thus, we chose the value of $20 \%$ in this study. The $20 \%$ leather yield meant that to produce $1 \mathrm{~kg}$ of cowhide upper leather, $5 \mathrm{~kg}$ of raw hide was required 
and input into the manufacturing process. In addition, power consumption data came from an overall estimate of working hours and efficiency of all production and processing equipment. By recording the working time and energy consumption of each machine on the spot, it is calculated that electrical energy consumption in the entire production processes was $30 \mathrm{kw} / \mathrm{h}$ per $1 \mathrm{~kg}$ of finished leather.

Table 1: Process flow

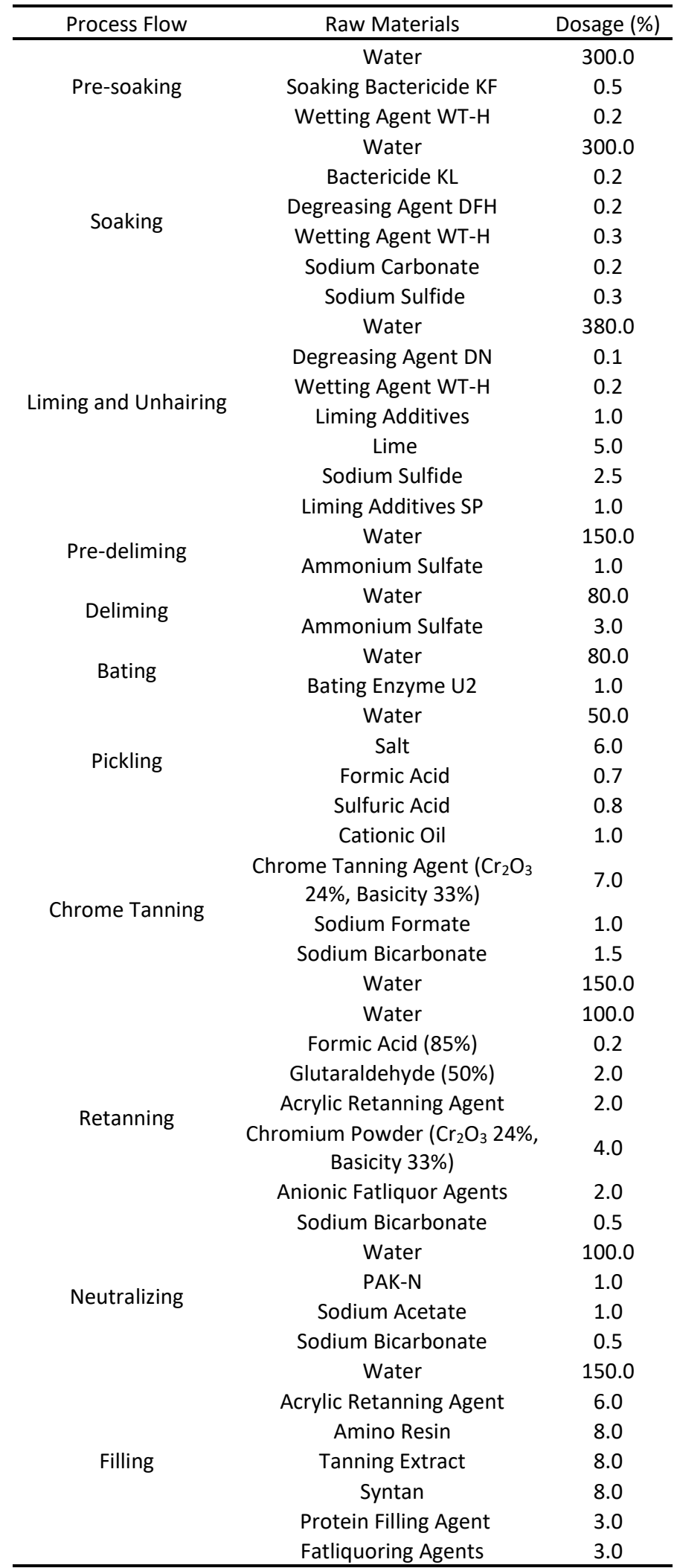




\begin{tabular}{ccc}
\hline Process Flow & Raw Materials & Dosage (\%) \\
\hline \multirow{3}{*}{ Fatliquoring and Dyeing } & Formic Acid (85\%) & 1.0 \\
& Water & 100.0 \\
& Dyestuff & 2.0 \\
& Fatliquoring Agents & 7.0 \\
& Formic Acid (85\%) & 2.0 \\
Base Coating & Water & 300.0 \\
& Pigment Paste 2.0 & 10.0 \\
& Acrylate Resin Emulsion s-1 & 2.0 \\
& Filler Resin & 2.0 \\
& Water & 710.0 \\
Top Coating & Pigment Paste 2.0 & 10.0 \\
& Casein Solution & 1.3 \\
& Urethane Resin & 4.0 \\
& Filling Agent & 0.2 \\
\hline
\end{tabular}

\section{Life Cycle Impact Assessment}

Life cycle impact assessment ( $\mathrm{LCIA})$ is a qualitative and quantitative method to explain the environmental impact identified by $\mathrm{LCl}$ and determine the impact of the material and energy exchange of the system on the external environment. Through LClA, four environmental impacts most closely related to our target product were determined: primary energy demand (PED, MJ), global warming potential (GWP, $\mathrm{kg} \mathrm{CO}_{2} \mathrm{eq}$ ), water utility (WU, $\mathrm{kg}$ ) and acidification (AP, $\mathrm{kg} \mathrm{SO} \mathrm{S}_{2}$ eq). By considering these indicators, we gained insights into the impact of the leather manufacturing process on the environment.

\section{Modelling Process}

Figure 2 showed the modelling sequences. First, specific materials related to by-products, renewable energy consumption and waste recycling treatment were neglected; meanwhile, according to the rule of CLCD, raw materials used less than or equal to $1 \%$ of the production target mass and those lacking of traceable upstream sources were then regarded to have zero environmental impact. These data would not enter the LCA modelling process. Additionally, this study complied with the integrity check of the LCA study.

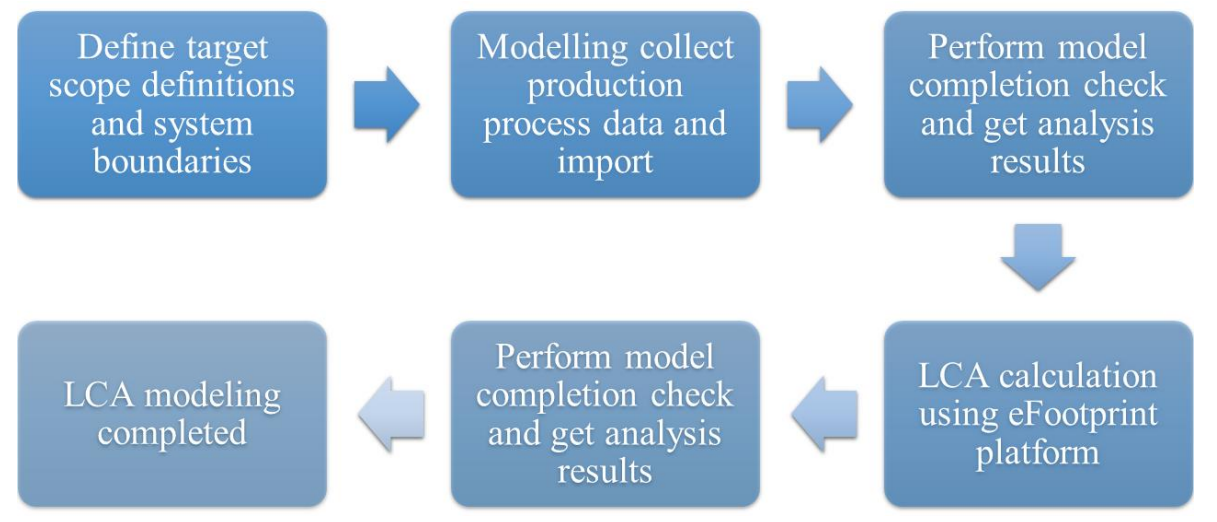

Figure 2. Modelling flow chart of chrome tanned cowhide upper leather

\section{RESULTS AND DISCUSSION}

The environmental impacts of chrome tanned cowhide upper leather with a functional unit of $1 \mathrm{~kg}$ were evaluated in this study. The four main indicators were applied to gain insights into the influence of manufacturing processes on the environment.

As shown in Figure 3, the GWP, PED, WU and AP of $1 \mathrm{~kg}$ of cowhide leather produced by chrome tanning were $7.040 \mathrm{~kg} \mathrm{CO}_{2}$ eq, 106.793 $\mathrm{MJ}, 89.144 \mathrm{~kg}$ and $0.058 \mathrm{~kg} \mathrm{SO} \mathrm{SO}_{2}$ eq, 
respectively; the source of AP was ammonium sulphate. In general, the AP and GWP during the process was limited, whereas PED and WU were relatively large. Especially, water was significantly consumed in the beamhouse and tanning section, thus contributing a relatively higher value of WU.

\section{LCIA Results}

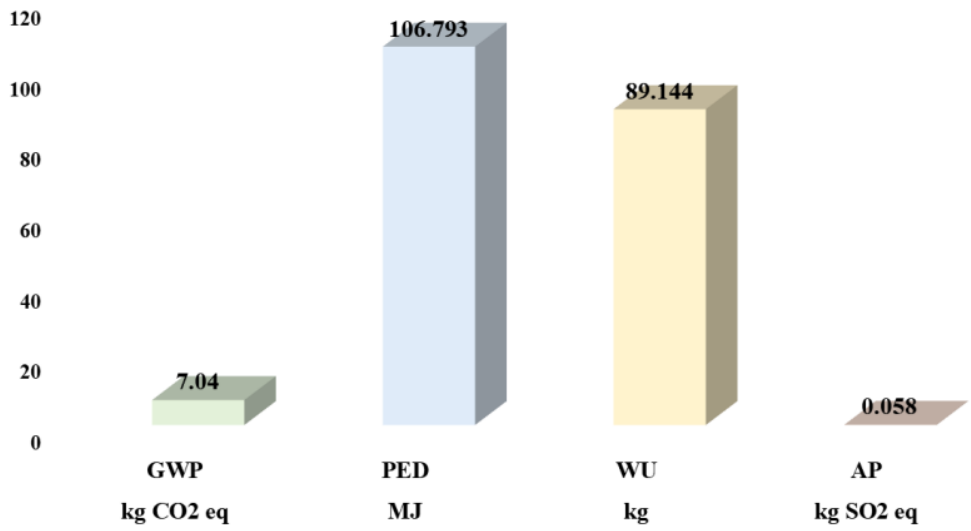

Figure 3. LCIA: Environmental impact potential of chrome tanned cowhide upper leather

Combining $\mathrm{LClA}$ and $\mathrm{LCl}$, we could understand environmental impact from the viewpoint of manufacturing process. Our findings suggested that the tanning section was responsible for the majority of PED and GWP values, whereas the beamhouse had the largest water consumption. Furthermore, deliming, chrome tanning and retanning caused environment significant acidification.

Given the considerable impact of the tanning section in terms of GWP and PED, we could hypothesise that chemical usage is a major factor; thus, a comparison was performed between chrome tanning and chrome-free tanning. The chromium free tanning process consisted on using a yellowishclear-bright-liquid polymer-modified glutaraldehyde (without free formaldehyde). In Figure 4, results presented a clear preference for the chrome-free tanning process, which reduces the GWP impact by $42 \%$ in comparison with the chrome tanning process, whereas PED in the chrome-free tanning process was $21 \%$ lower than in that in chrome tanning [14]. Therefore, chrome-free tanning technologies, such as titanium tanning, vegetable tanning and organic phosphine tanning, could be considered to reduce GWP and PED [15-17].

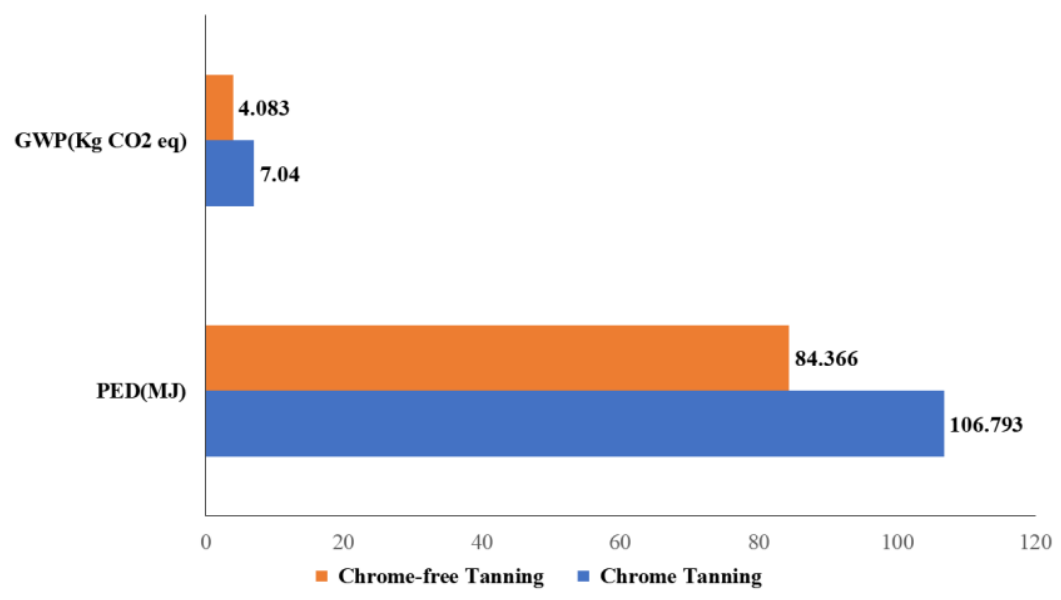

Figure 4. LCIA: GWP and PED results 
In terms of PED, the tanning section used more than $92 \%$ of the total power in leather making. According to the technologies list, we found hour- or even day-long drum running in these two procedures. Therefore, machinery power consumption was the major source of

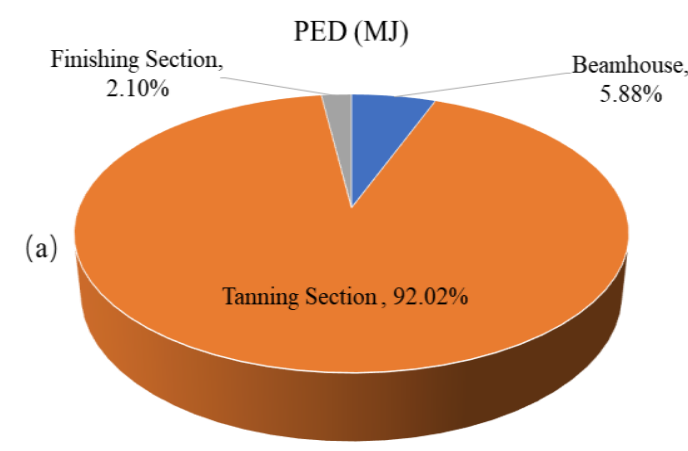

- Beamhouse $=$ Tanning Section $\approx$ Finishing Section
PED. To reduce PED, the tanning process must be improved using ultrasound, microwave or other methods to reduce tanning time and improve tanning agent exhaustion $[18,19]$. In addition, chrome-free tanning could be applied in tannery. Figure 5. LCl: Inventory data sensitivity of
the tanning section accounted for approximately $88 \%$, whereas the beamhouse and finishing sections accounted for $10.67 \%$ and $1.01 \%$, respectively. During the tanning and retanning processes, chromium powder was largely used. According to the CLCD-ChinaECER 0.8.1 database, the mining process of chromium powder emitted substantial carbon dioxide. Therefore, the results indicated that the chromium powder utilised in these two processes accounted for $44 \%$ of GWP. Therefore, focus must be shifted to the application of chromium powder, and alternative agents must be identified to reduce carbon dioxide emissions during leather

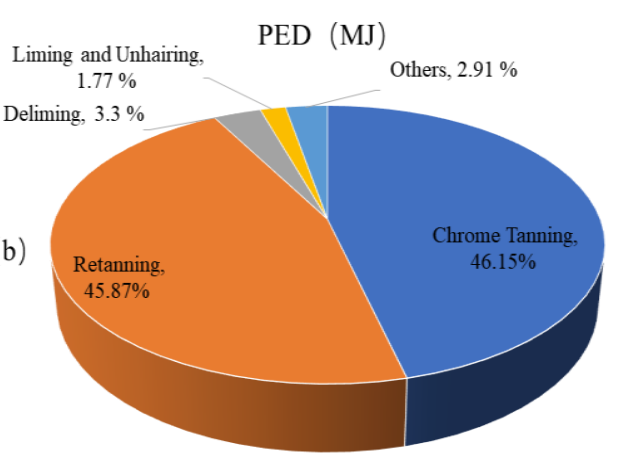

- Chrome Tanning | Retanning | Deliming |" Liming and Unhairing | Others

(a) based on section, (b) based on process

making [20]. Similarly, the effects of sodium sulphide and lime during the unhairing and liming processes on carbon dioxide emissions were substantial; enzyme unhairing and collagen fibre opening without lime may be potential options [21-23]. Cleaner methods for tanning and retanning sections have also been discussed by Giannetti [24], who proved that lime and tanning float recovery reduces sodium sulphide, lime and chromium consumption during effluent treatment for unhairing and tanning. Other innovations, including the use of lower dosages of chemical materials in leather making, could also reduce environmental impact.
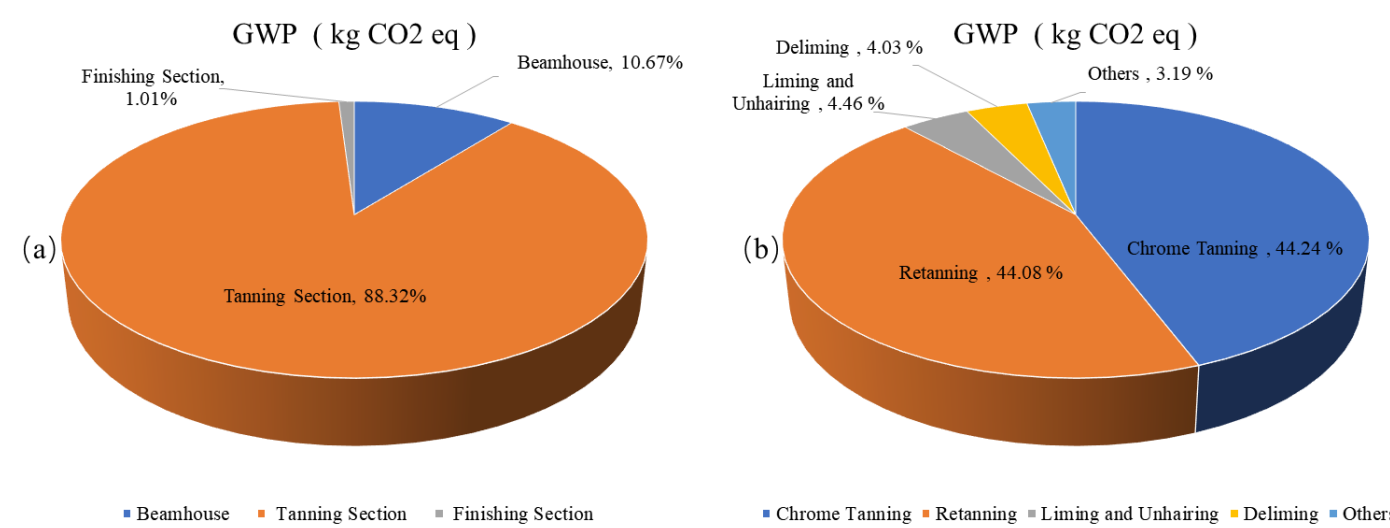

- Chrome Tanning $"$ Retanning $\|$ Liming and Unhairing $"$ Deliming $"$ Others

Figure 6. LCl: Inventory data sensitivity of GWP: (a) based on section, (b) based on process 
Figure 7 showed the results of the indepth study conducted on a beamhouse. Results showed that the pickling process contributed to GWP because of salt usage. Saltfree or low-salt pickling was an effective approach to decrease the usage of salt. Luo et al. [25] developed a nonpickling chrome tanning technology in which a macromolecular aliphatic aldehyde was synthesised and used to pre-tan bated pelt prior to chrome tanning, eventually eliminating the conventional pickling process. The results showed that the performance of leather produced using this technology was comparable to conventionally processed leather in terms of hydrothermal stability and property evaluation. Hence, saltfree or low-salt pickling could be widely applied in tanneries to decrease GWP.

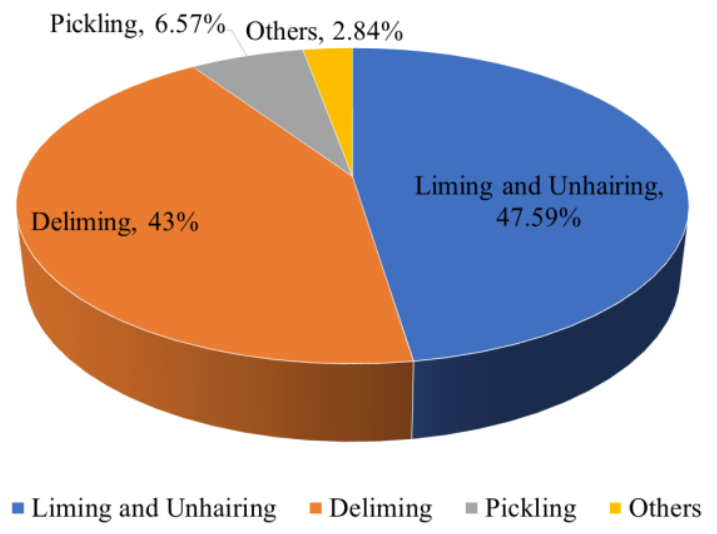

Figure 7. Inventory data sensitivity: GWP of the beamhouse

As shown in Figure 8, the beamhouse accounted for more than $71 \%$ of WU. The entire tanning process also occupied $23.24 \%$. Figure 9 showed that almost every process, especially washing, in the beamhouse consumed a substantial amount of water; thus, water reduction strategies must focus on the beamhouse.

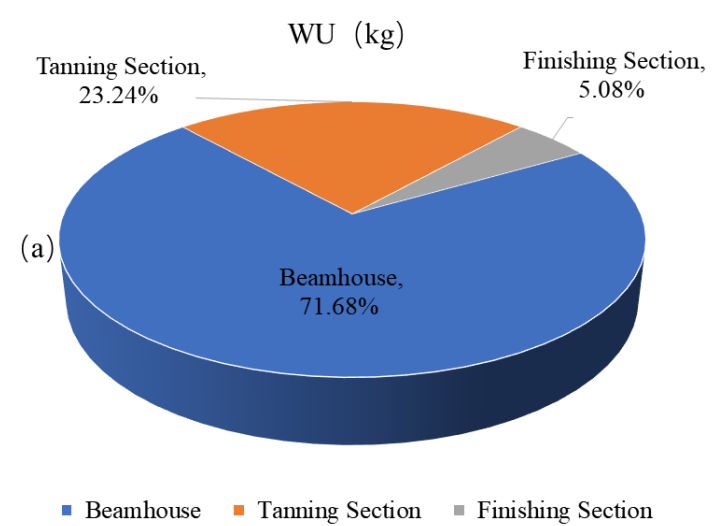

To reduce $\mathrm{WU}$, the washing equipment could be strengthened, and washing using running water should be eliminated. In addition, the recycling of effluent would be a practical and effective way for tanneries to reduce $\mathrm{WU}$, e.g., treated wastewater after the tanning process could be used for the next washing and pickling processes [26].

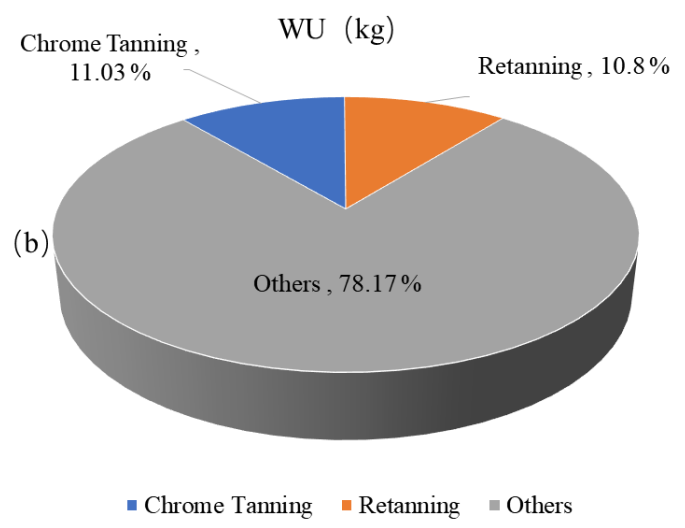

Figure 8. LCl: Inventory data sensitivity of WU: (a) based on section, (b) based on process 


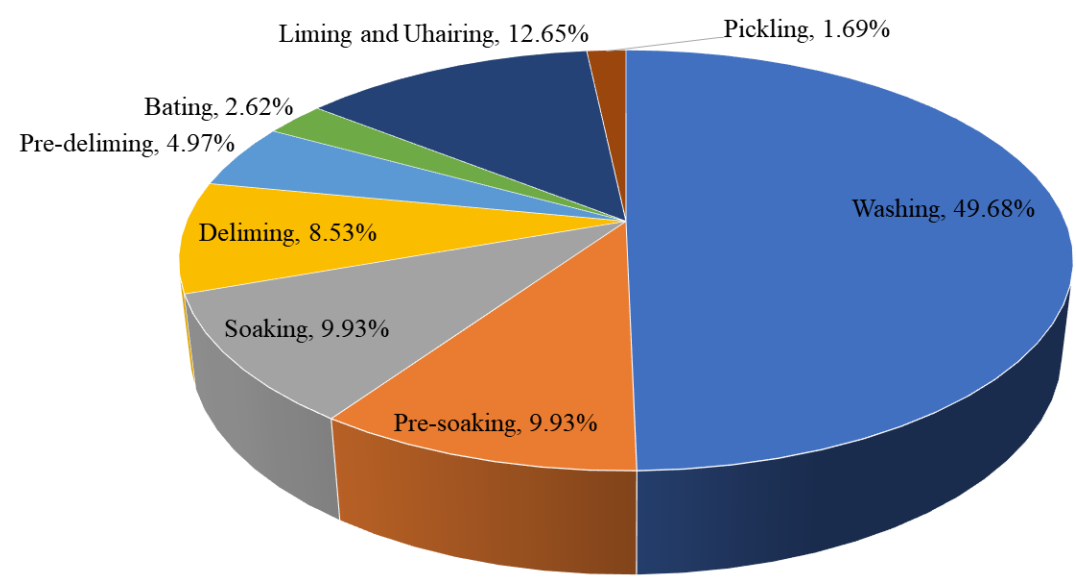

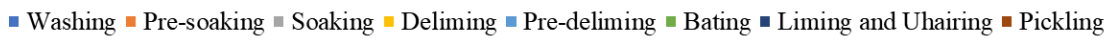

Figure 9. Inventory data sensitivity: WU of the beamhouse

In terms of $\mathrm{AP}$, the tanning section accounted for approximately $91 \%$ of the total $A P$, whereas the beamhouse accounted for $8.23 \%$. The contribution of deliming, chrome tanning and retanning was prominent due to the usage of chromium powder in the tanning section and the sulphides generated during deliming. According to the upstream database, the exploitation and synthesis of chrome powder caused the acidification of the environment. Therefore, the use of alternative raw materials was encouraged. Enzymes are a

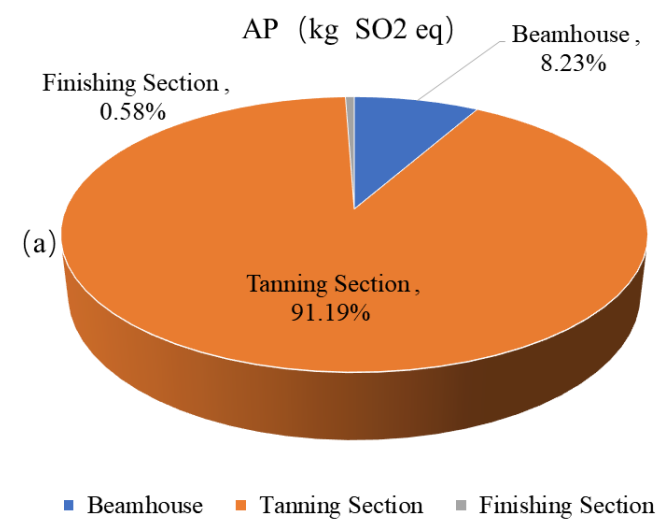

high-efficiency unhairing agent; hence, their usage can reduce the amount of sodium sulphide and minimise the generation of hydrogen sulphide during deliming. Ammonium-free and chrome-free tanning agents could also be applied to reduce the acidification of the environment [27]. In addition, electrochemical and photo-assisted electrochemical oxidation processes could be used to convert sulphide to sulphate in tannery lime wastewater (wastewater from the deliming process) to diminish AP [28].

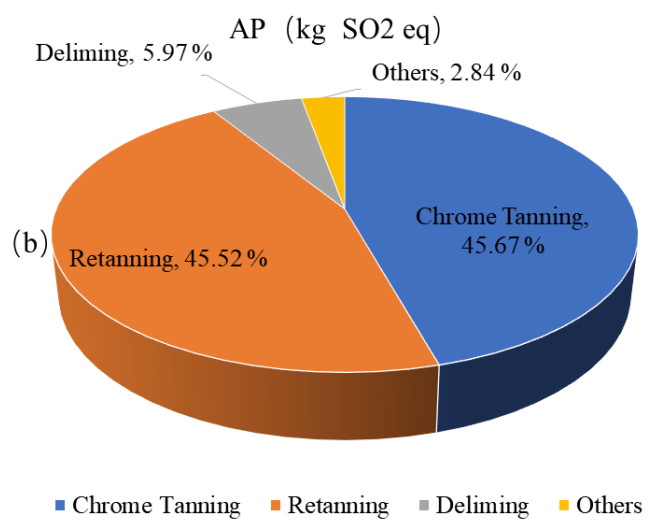

Figure 10. LCl: Inventory data sensitivity of AP: (a) based on section, (b) based on process

Although this study completed LCA modelling for the manufacturing process of chrome tanned cowhide upper leather, it still has a few limitations. First, the data of raw materials not included in the upstream database were not input to the calculation; these materials included rising cowhide and animal slaughter. Second, the results might not be compatible for all tanning industries because the production data of different tanneries vary widely [29]. Future research will be conducted on other leather manufacturing technologies to achieve wide and reliable application. 


\section{CONCLUSION}

When we obtain $1 \mathrm{~kg}$ of chrome tanned cowhide upper leather, we usually generate considerably negative influences on the environment; meanwhile, the usage of chromium powder in tanning and retanning process, as well as sodium sulphide and lime in the liming and unhairing are primary causes. Overall, technological innovations, particularly for the beamhouse, tanning and retanning sections, should be seriously considered. Furthermore, the use of eco-friendly alternative materials or biomaterials is encouraged to improve the cleanliness and sustainability of the leather-making process.

\section{Acknowledgements}

The authors appreciated supports from IKE in assisting LCA model and results interpretations; meanwhile we also thank the financial support from Natural Science Foundation of China (31700813), China Postdoctoral Science Foundation (2015M571896) and Sichuan Science and Technology Program (2020YFH0068).

\section{Conflicts of Interest}

The authors declared no conflict of interest. No subjects or animals were included in this study. Neither participants nor informed consent were included in the study.

\section{Author Contributions}

Heng Yang: the first author, responsible for data analysis and manuscript writing;

Dexin An: responsible for data analysis of this study;

Carmen Gaidau: assisting for the review of the manuscript;

JinWei Zhang: responsible for data analysis and manuscript review;

Jin Zhou: the corresponding author, responsible for all the procedure of this study and manuscript review.

\section{REFERENCES}

1. Shi, J., Puig, R., Sang, J., Lin, W., A comprehensive evaluation of physical and environmental performances for wet-white leather manufacture, J Clean Prod, 2016, 139, 1512-1519, https://doi.org/10.1016/j.jclepro.2016.08. 120.

2. Yang, S.S., Status and development trend of domestic leather chemical industry, Beijing Leather, 2019, 09, 66-68.

3. Zhao, C., Chen, W., A review for tannery wastewater treatment: some thoughts under stricter discharge requirements, Environ Sci Pollut R, 2019, 26(25), 2610226111, https://doi.org/10.1007/s11356019-05699-6.

4. Kanchinadham, S.B.K., Kalyanaraman, C., Carbon trading opportunities from tannery solid waste: a case study, Clean Tech Environ, 2017, 19(4), 1247-1253, https://doi.org/10.1007/s10098-016-1313-x.

5. Deng, W., Chen, D., Huang, M., Hu, J., Chen, L., Carbon dioxide deliming in leather production: a literature review, $J$ Clean Prod, 2015, 87, 26-38, https://doi.org/10.1016/j.jclepro.2014.09. 066.

6. Kılıç, E., Puig, R., Zengin, G., Adıgüzel Zengin, C., Fullana-i-Palmer, P., Corporate carbon footprint for country Climate Change mitigation: A case study of a tannery in Turkey, Sci Total Environ, 2018, 635, 60-69, https://doi.org/10.1016/j.scitotenv.2018.0 4.111.

7. Tasca, A.L., Puccini, M., Leather tanning: Life cycle assessment of retanning, fatliquoring and dyeing, J Clean Prod, 2019, 226, 720-729, https://doi.org/10.1016/j.jclepro.2019.03. 335.

8. Chen, K.W., Lin, L.C., Lee, W.S., Analyzing the Carbon Footprint of the Finished Bovine Leather: A Case Study of Aniline Leather, Energy Procedia, 2014, 61, 10631066, https://doi.org/10.1016/j.egypro.2014.11. 1023.

9. Chen, M., Duan, Y., Dong, L., Chen, M., Cheng, H., Country-level Life Cycle Assessment of Carbon Footprint in Processing of Bovine Upper Leather, J Am Leather Chem Assoc, 2019, 114, 6, 194-203.

10. Baquero, G., Sorolla, S., Olle, L., Bacardit, A., Environmental Assessment of 
Dehydration Processes for Bovine Hides, J Am Leather Chem Assoc, 2017, 112, 03, 102-108.

11. Proske, M., Finkbeiner, M., Obsolescence in LCA-methodological challenges and solution approaches, Int J Life Cycle Assess, 2019, 25, 3, 495-507, https://doi.org/10.1007/s11367-01901710-x.

12. Software of efootprint Home Page, available online: http://www.efootprint.net/\#/home (accessed on 9 December 2019).

13. Cabeza, L.F., Taylor, M.M., Dimaio, G.L., Brown, E.M., Marmer, W.N., Carrió, R., Celma, P.J., Cot, J., Processing of leather waste: pilot scale studies on chrome shavings. Isolation of potentially valuable protein products and chromium, Waste Manage, 1998, 18, 3, 211-218, https://doi.org/10.1016/S0956053X(98)00032-4.

14. Xu, X., Baquero, G., Puig, R., Shi, J., Sang, J., Lin, W., Carbon footprint and toxicity indicators of alternative chromium free tanning in China, J Am Leather Chem Assoc, 2015, 110, 05, 130-137.

15. Zuriaga-Agusti, E., Galiana-Aleixandre, M.V., Bes-Pia, A., Mendoza-Roca, J.A., Risueño-Puchades, V., Segarra, V., Pollution reduction in an eco-friendly chrome-free tanning and evaluation of the biodegradation by composting of the tanned leather wastes, J Clean Prod, 2015, 87, 874-881, https://doi.org/10.1016/j.jclepro.2014.10. 066.

16. Auad, P., Spier, F., Gutterres, M., Vegetable tannin composition and its association with the leather tanning effect, Chem Eng Commun, 2020, 207, 5, 722-732, https://doi.org/10.1080/00986445.2019.1 618843.

17. Shao, S., Shi, K., Li, Y., Jiang, L., Ma, C., Mechanism of Chrome-free Tanning with Tetra-hydroxymethyl Phosphonium Chloride, Chinese J Chem Eng, 2008, 16, 3, 446-450, https://doi.org/10.1016/S10049541(08)60103-2.

18. Zhang, J.W., Chen, W.Y., Gaidau, C., Microwave irradiation: an innovative routine to promote goat skin chrome tanning process, J Am Leather Chem Assoc, 2019, 114, 287-292.

19. Zhang, J.W., Chen, W.Y., A rapid and cleaner chrome tanning technology based on ultrasound and microwave, J Clean Prod, 2019, 247, 119452, https://doi.org/10.1016/j.jclepro.2019.119 452.

20. Cui, L., Qiang, X., Clean Production for Chrome Free Leather by Using a Novel Triazine Compound, J Renew Mater, 2019, 7, 1, 57-71, https://doi.org/10.32604/jrm.2019.00118.

21. Garro, M.L., Galarza, B.C., Greco, C.A., Hours, R.A., Unhairing of Bovine Skin with Fungal Enzymes by Immersion and Spread Throughout the Epidermis, J Soc Leath Tech Ch, 2019, 103, 1, 28-34.

22. Cao, S., Li, D., Ma, X., Xin, Q., Song, J., Lu, F., Li, Y., A novel unhairing enzyme produced by heterologous expression of keratinase gene (kerT) in Bacillus subtilis, World J Microb Biot, 2019, 35, 8, 122.

23. Irvaityt, J., Beleka, K., Valeika, V., Lime Free Unhairing: Sodium Aluminate as an Alternative Towards a Cleaner Process, $J$ Am Leather Chem Assoc, 2016, 111, 11, 406-412.

24. Giannetti, B.F., Agostinho, F., Moraes, L.C., Almeida, C.M.V.B., Ulgiati, S., Multicriteria cost-benefit assessment of tannery production: The need for breakthrough process alternatives beyond conventional technology optimization, Environ Impact Assess Rev, 2015, 54, 22-38, https://doi.org/10.1016/j.eiar.2015.04.00.

25. Luo, J.X., Li, J., Liao, X.P., Cleaner chrome tanning-a non-pickling process using an aliphatic aldehyole as a pre-tanning agent, J Soc Leath Tech Ch, 2012, 96, 1, 21-26.

26. Yin, Q.T., Wang, G., Zhang, L.L. et al., The Liming Process and Chrome Tanning Waste Water Recycle Utilization, Leather Sci Eng, 2016, 026, 001, 43-49.

27. Lei, C., Lin, Y., Zeng, Y., Wang, Y., Yuan, Y., Shi, B., A cleaner deliming technology with glycine for ammonia-nitrogen reduction in leather manufacture, J Clean Prod, 2020, 245, 118900, https://doi.org/10.1016/j.jclepro.2019.118 900. 
28. Selvaraj, H., Aravind, P., George, H.S., Sundaram, M., Removal of sulfide and recycling of recovered product from tannery lime wastewater using photoassisted-electrochemical oxidation process, J Ind Eng Chem, 2020, 83, 164172, https://doi.org/10.1016/j.jiec.2019.11.024.

29. Laurenti, R., Redwood, M., Puig, R., Frostell, B., Measuring the environmental footprint of leather processing technologies, J Ind Eco, 2017, 21, 5, 11801187, https://doi.org/10.1111/jiec.12504.
(C) 2021 by the author(s). Published by INCDTPICPI, Bucharest, RO. This is an open access article distributed under the terms and conditions of the Creative Commons Attribution license (http://creativecommons.org/licenses/by/4.0/). 